\title{
Magnetic and Spectroscopic Studies of the Synthesized Metal Complexes of Bis(Pyridine-2- carbo) Hydrazide and Their Antimicrobial Studies
}

\author{
NETRA PAL SINGH ${ }^{*}$, ANU, AND JAGVIR SINGH \\ Department of Chemistry \\ Meerut College, CCS University, Meerut, U.P.-250001, India \\ np_singh71@rediffmail.com
}

Received 1 August 2011: Accepted 4 October 2011

\begin{abstract}
Cobalt(II), Nickel(II), Copper(II) and Manganese(II) complexes, having the general composition $\left\{\mathrm{M}(\mathrm{L})_{2} \mathrm{X}_{2}\right\}$, have been synthesized [where $\mathrm{L}=$ bis(pyridine-2-carbo) hydrazide $(\mathrm{L})$, and $\left.\mathrm{X}=\mathrm{Cl}^{-}\right]$. All the Metal complexes reported here have been characterized by elemental analysis, molar conductance, magnetic moments, IR, electronic and mass spectral studies. All the complexes were found to have magnetic moments corresponding to unpaired electrons. The possible geometries of the complexes were assigned on the basis of electronic and infrared spectral studies. On the basis of molar conductance values the complexes show 1:2 electrolytic nature. Newly synthesized ligand and its Metal complexes have been screened against Staphylococcus aureus (ATCC 25923), Staphylococcus aureus (ATCC 3160) bacterial species and Candida albicans (227) and Staphylococcus cereviscae (361) fungal species.
\end{abstract}

Keywords: Hydrazide, Transition metal complexes, Spectroscopic and biological screening.

\section{Introduction}

$N$-substituted hydrazides are analogous to primary amino compounds, which act as negatively charged ligands toward metal ions ${ }^{1}$, coordination occurring through both the $\mathrm{NH}_{2}$ and $\mathrm{CHO}$ or $\mathrm{C}=\mathrm{O}$ groups ${ }^{2}$ in majority of the cases. The pyridine derivatives of $\mathrm{N}$-substituted hydrazides have already been established to be potential chelating agents and some of them have been found to possess biological activity. $N$-substituted hydrazides are of wide interest because of their diverse biological ${ }^{3-5}$ and clinical applications $\mathrm{s}^{6-8}$. This created interest in researchers who have synthesized variety of hydrazide derivatives and screened them for their various biological activities. In the present study, we have made an attempt to collect biological properties of hydrazide derivatives reported in the new millennium. Transition metal complexes having the ability to bind and cleave DNA under physiological conditions are of current interests for their potential applications ${ }^{9-13}$ in nucleic acid chemistry. Such complexes ${ }^{14}$ are useful in foot printing studies, as sequence specific DNA binding agents, in genomic research and as diagnostic agents in medicinal applications. Much attention has been paid to biologically active metal complexes in recent years. Oxygen and nitrogen donor ligands ${ }^{15,16}$ have been widely studied due to their high potential 
to coordinate with transition metals. Compounds containing azomethine nitrogen and carbonyl oxygen groups ${ }^{17-22}$ have important position among organic reagents as potential donor ligands for the transition metal ions. Organic compounds and metal complexes ${ }^{23-26}$ both display a wide range of pharmacological activity including anticancer, antibacterial, and fungi static effects.

Our research was on going to establish the fact that non-biologically active compounds become biologically active and less biologically active become more upon coordination /chelation with metal ions. In this article, we synthesized the bis(Pyridine-2-carbo) hydrazide and its metal complexes, were characterized by IR, NMR, Molar conductance and magnetic moments, elemental analysis, mass spectrum, and UV-Visible spectroscopy. Hydrazide ligand and their metal complexes were screened for their antimicrobial activity against Staphylococcus aureus (ATCC 25923), Staphylococcus aureus (ATCC 3160) bacterial species and Candida albicans (227) and Staphylococcus cereviscae (361) fungal species. The hydrazide showed varied antibacterial and antifungal activity against one or more strains respectively and their activity was enhanced on coordination or chelation.

\section{Experimental}

All the chemicals used in the present investigation were of the analytical reagent grade (AR). Pyridine 2-acetyl chloride (Fisher Scientific), Hydrazine (Chemical Drug House, India), all metal salts and solvents (Qualigens Fine Chemicals, India) were purchased and used as received. The elemental analysis $(\mathrm{C}, \mathrm{H}, \mathrm{N})$ done at the Regional Sophisticated Instrumentation Centre, Central Drug Research Institute, Lucknow. ${ }^{1} \mathrm{H}$ NMR and ${ }^{13} \mathrm{C}$ NMR spectra of the samples were measured in DMSO-d $\mathrm{d}_{6}$ at IIT Delhi, India. The IR spectra were recorded as $\mathrm{KBr}$ pellets using a Perkin-Elmer 783 spectrophotometer in the range $4000-400 \mathrm{~cm}^{-1}$. UV-vis spectra of the complexes were recorded on a Shimadzu UV-1601 spectrophotometer.

\section{Synthesis of Hydrazide Ligand}

\section{Bis(Pyridine-2-carbo) hydrazide}

In a round bottom flask $(100 \mathrm{~mL})$, a methanolic solution $(10.0 \mathrm{~mL})$ of Pyridine 2-Acetyl chloride $(0.02 \mathrm{~m} \mathrm{~mol}, 2.62 \mathrm{~mL})$ and an aqueous methanolic solution $(10 \mathrm{~mL})$ of hydrazine $(0.01 \mathrm{~m} \mathrm{~mol}, 0.32 \mathrm{~g})$ were taken and stirred at room temperature for 30 minutes after then the reaction mixture refluxed at $65^{\circ} \mathrm{C}$ for $12 \mathrm{~h}$. The resulting solution was cooled at room temperature and after the completion of this reaction; the reaction mixture was monitored by thin layer chromatography. After this, the reaction mixture was taken in chloroform and washed with water $(3 \times 20 \mathrm{~mL})$ (thrice) and then with brine solution $(3 \times 20 \mathrm{~mL})$ (thrice). The organic layers were collected and then evaporate the solvent under reduced pressure to afford the product (Scheme 1).

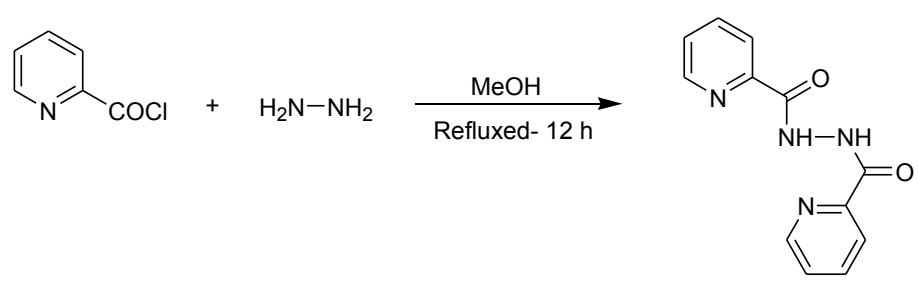

Scheme 1. The synthesis of the Ligand. 


\section{Analytical Data of Ligand}

Ligand $\left(\mathrm{C}_{12} \mathrm{H}_{10} \mathrm{~N}_{4} \mathrm{O}_{2}\right)$ : Yield: 52\%; M.P. $190{ }^{\circ} \mathrm{C}$, Mol. wt. 242, color: yellow; analytical data for found (calc.): C, 59.50 (59.11); H, 4.13 (4.11); N, 23.14 (22.97). IR (KBr, cm $\left.{ }^{-1}\right) 3440 \mathrm{v}$ ${ }_{\mathrm{NH}}, 1690 v_{\mathrm{C}=\mathrm{O}}, 3015 v_{\mathrm{C}-\mathrm{H}}, 2228 v_{\mathrm{C}-\mathrm{N}}$. ESI-MS, m/z Data found (calc.): $242(241),{ }^{1} \mathrm{H}$ NMR (DMSO-d 6 ) $\delta$ ppm: 7.1 (m, 8H, HC-Ar), 3.8 (s, 2H, NH-NH). ${ }^{13} \mathrm{C}$ NMR (DMSO-d $\left.\mathrm{d}_{6}\right) \delta$ ppm: 117.53-121.07 (10C, CH-Ar.), 143.23 (1C, C-N), 153.88 (2C, C=O).

General Procedures for the Synthesis of Metal Complexes via the Reaction of Ligand

In a round bottom flask $(100 \mathrm{~mL})$, a mixture of ligand $(0.002 \mathrm{~mol}, 0.484 \mathrm{~g})$ in an aqueous ethanolic solution $(15 \mathrm{~mL})$ and a solution of $\left[\mathrm{CuCl}_{2} .2 \mathrm{H}_{2} \mathrm{O}(0.001 \mathrm{~mol}, 0.0462 \mathrm{~g})\right]$ in an methanolic solution $(10 \mathrm{~mL})$ were taken then the reaction mixture was refluxed at $75^{\circ} \mathrm{C}$ for $18 \mathrm{~h}$. The resulting solution was cooled at freezing point $4{ }^{\circ} \mathrm{C}$, after the completion of this reaction; the reaction mixture was monitored by thin layer chromatography. After this, the reaction mixture was taken in chloroform and washed with water $(3 \times 20 \mathrm{~mL})$ and then with brine solution $(3 \times 20 \mathrm{~mL})$. The organic layers were collected and then evaporate the solvent under reduced pressure to afford the product; a bluish crystalline solid was obtained. Similarly, other complexes have been synthesized and well characterized as above.

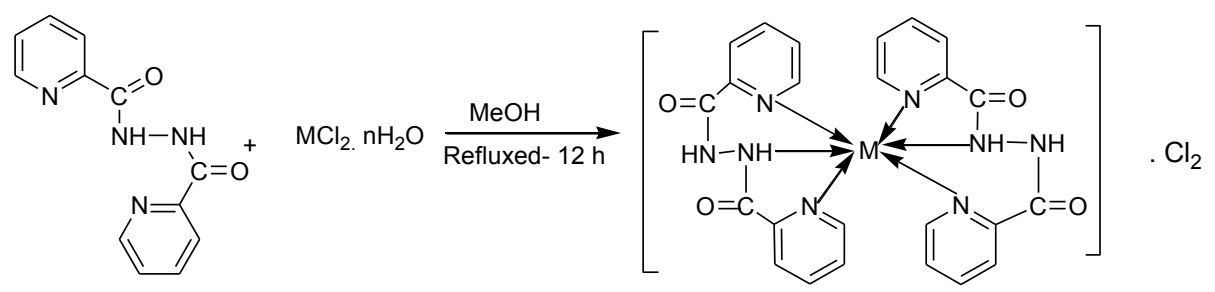

Scheme 2. Synthesis of the metal complexes (I, II, III and IV).

\section{Complex I}

Yield: $38 \%$; MP: $320^{\circ} \mathrm{C}$; Mol. wt. 751 ; color: brown; analytical data for $\left[\mathrm{MnC}_{24} \mathrm{H}_{20}\right.$ $\mathrm{N}_{8} \mathrm{O}_{4} \mathrm{Cl}_{2}$ ] found (calc.): C, 38.34 (38.30), $\mathrm{H}, 2.66$ (2.01), N, 14.91 (14.17). (KBr, cm $\left.{ }^{-1}\right) 3400$ $v_{\mathrm{NH}}, 1690 v_{\mathrm{C}=\mathrm{O}}, 3015 v_{\mathrm{C}-\mathrm{H}}, 2200 v_{\mathrm{C}-\mathrm{N}}, 512 v_{\mathrm{M}-\mathrm{N}}$. ESI-MS, m/z data found (calc.): 775 (774), ${ }^{1} \mathrm{H}$ NMR (DMSO-d $\left.{ }_{6}\right) \delta$ ppm: 7.1 (m, 8H, HC-Ar), 3.4 (s, 2H, NH-NH). ${ }^{13} \mathrm{C}$ NMR (DMSO$\left.\mathrm{d}_{6}\right) \delta$ ppm: 117.53-121.07 (10C, CH-Ar.), $131.20(1 \mathrm{C}, \mathrm{C}-\mathrm{N}), 153.88(2 \mathrm{C}, \mathrm{C}=\mathrm{O})$.

\section{Complex II}

Yield: $60 \%$; MP: $245^{\circ} \mathrm{C}$, Mol. wt. 724 ; color: bluish; analytical data for $\left[\mathrm{CuC}_{24} \mathrm{H}_{20} \mathrm{~N}_{8} \mathrm{O}_{4} \mathrm{Cl}_{2}\right.$ ] found (calc.): C, 39.77 (38.85); H, $2.76(2.01)$; N, $15.46(14.17) .\left(\mathrm{KBr}, \mathrm{cm}^{-1}\right) 3402 v_{\mathrm{NH}}$, $1690 v_{\mathrm{C}=\mathrm{O}}, 3015 \mathrm{v}_{\mathrm{C}-\mathrm{H}}, 2210 \mathrm{v}_{\mathrm{C}-\mathrm{N}}, 544 \mathrm{v}_{\mathrm{M}-\mathrm{N}}$. ESI-MS, m/z data found (calc.): $770(769),{ }^{1} \mathrm{H}$ NMR (DMSO-d $\left.\mathrm{d}_{6}\right) \delta$ ppm: 7.1 (m, 8H, HC-Ar), 3.2 (s, 2H, NH-NH). ${ }^{13} \mathrm{C}$ NMR (DMSO-d $\left.\mathrm{d}_{6}\right) \delta$ ppm: 117.53-121.07 (10C, CH-Ar.), $135.13(1 \mathrm{C}, \mathrm{C}-\mathrm{N}), 153.88(2 \mathrm{C}, \mathrm{C}=\mathrm{O})$.

\section{Complex III}

Yield: $55 \%$; MP: $270^{\circ} \mathrm{C}$; Mol. wt. 791; color: reddish; analytical data for $\left[\mathrm{CoC}_{24} \mathrm{H}_{20}\right.$ $\mathrm{N}_{8} \mathrm{O}_{4} \mathrm{Cl}_{2}$ ] found (calc.): $\mathrm{C}, 36.40$ (35.15); $\mathrm{H}, 2.52$ (2.11); N, 14.15 (13.17); $\left(\mathrm{KBr}, \mathrm{cm}^{-1}\right) 3406$ $v_{\mathrm{NH}}, 1690 v_{\mathrm{C}=\mathrm{O}}, 3015 v_{\mathrm{C}-\mathrm{H}}, 2203 v_{\mathrm{C}-\mathrm{N},} 519 v_{\mathrm{M}-\mathrm{N}}$. ESI-MS, m/z data found (calc.): 771 (770), 
${ }^{1} \mathrm{H}$ NMR (DMSO-d $\left.\mathrm{d}_{6}\right) \delta$ ppm: 7.1 (m, 8H, HC-Ar), 3.01 (s, 2H, NH-NH). ${ }^{13} \mathrm{C}$ NMR (DMSO$\left.\mathrm{d}_{6}\right) \delta$ ppm: 117.53-121.07 (10C, CH-Ar.), $133.22(1 \mathrm{C}, \mathrm{C}-\mathrm{N}), 153.88(2 \mathrm{C}, \mathrm{C}=\mathrm{O})$.

\section{Complex IV}

Yield: $23 \%$; MP: $260^{\circ} \mathrm{C}$; Mol. wt. 792; color: greenish; analytical data for $\left[\mathrm{NiC}_{24} \mathrm{H}_{20}\right.$ $\mathrm{N}_{8} \mathrm{O}_{4} \mathrm{Cl}_{2}$ ] found (calc.): C, 36.36 (36.05); H, 2.52 (2.15); N, 14.14 (13.65). $\left(\mathrm{KBr}, \mathrm{cm}^{-1}\right)$ $3400 v_{\mathrm{NH}}, 1690 v_{\mathrm{C}=\mathrm{O}}, 3015 v_{\mathrm{C}-\mathrm{H}}, 2210 v_{\mathrm{C}-\mathrm{N}}, 518 v_{\mathrm{M}-\mathrm{N}}$. ESI-MS, m/z data found (calc.): $727(728),{ }^{1} \mathrm{H}$ NMR (DMSO-d 6 ) $\delta$ ppm: 7.1 (m, 8H, HC-Ar), 3.5 (s, 2H, NH-NH). ${ }^{13} \mathrm{C}$ NMR (DMSO-d d $_{6} \delta$ ppm: 117.53-121.07 (10C, CH-Ar.), 136.30 (1C, C-N), 153.88 (2C, $\mathrm{C}=\mathrm{O})$.

\section{Microbiology Assay}

For the antibacterial and antifungal assays, the compounds were dissolved in dimethylformamide. Further dilutions of the compounds and standard drugs in the test medium were prepared at the required quantities of 500 and $1000 \mathrm{ppm}$ concentrations with dextrose broth. The minimum inhibitory concentrations (MIC) were determined using the two fold serial dilution technique. A control test was also performed containing inoculated broth supplemented at the same dilutions used in our experiments and found inactive in the culture medium. All the compounds were tested for their in vitro growth inhibitory activity against different bacteria and the fungus. Origins of bacterial strains are $S$. aureus ATCC 29253, S. aureus ATCC 3160, as Gram-positive. Gentamycin and Amphotericin B were used as control drugs. The data on the antimicrobial activity of the compounds and the control drugs as MIC values are given in Table 1.

Table 1. Antibacterial activity of transition metal complexes against S. aureus.

\begin{tabular}{|c|c|c|c|c|c|}
\hline \multirow{4}{*}{ Compounds } & \multirow{4}{*}{$\underset{\Xi}{\stackrel{E}{\Xi}}$} & \multicolumn{2}{|c|}{ (S.aureus) } & \multicolumn{2}{|c|}{ (S.aureus) } \\
\hline & & ATCC & 25923 & ATCC & 3160 \\
\hline & & 500 ppm & $1000 \mathrm{ppm}$ & 500 ppm & $1000 \mathrm{ppm}$ \\
\hline & & \multicolumn{2}{|c|}{ Inhibition zone Inhibition zone } & Inhibition zone & Inhibition zone \\
\hline \multirow[t]{2}{*}{ I } & 24 & 18.6 & 20.7 & 13.8 & 17.7 \\
\hline & 48 & 18.3 & 20.3 & 13.5 & 17.1 \\
\hline \multirow[t]{2}{*}{ II } & 24 & 18.8 & 20.7 & 13.9 & 17.9 \\
\hline & 48 & 18.5 & 20.1 & 13.5 & 17.4 \\
\hline \multirow[t]{2}{*}{ III } & 24 & 18.9 & 20.9 & 13.5 & 17.6 \\
\hline & 48 & 18.5 & 20.4 & 13.1 & 17.2 \\
\hline \multirow[t]{2}{*}{ IV } & 24 & 18.1 & 20.3 & - & - \\
\hline & 48 & 18.5 & 20.4 & - & - \\
\hline DMSO & 24 & 7.4 & 8.2 & 7.5 & 76 \\
\hline \multirow{3}{*}{$\begin{array}{l}\text { Gentamycin } \\
(100 \mathrm{ppm})\end{array}$} & 48 & 12.2 & 15 & 7.5 & 7.6 \\
\hline & 24 & 12.2 & 15 & 11 & 12.1 \\
\hline & 48 & 12.4 & 15 & 11 & 12.1 \\
\hline
\end{tabular}

The cultures were obtained from SRL broth for all the bacterial strains after $24 \mathrm{~h}$ of incubation at $37^{\circ} \mathrm{C}$. C. albicans were maintained in dextrose broth after incubation for $25^{\circ} \mathrm{C}$ at $24 \mathrm{~h}$, testing was carried out in dextrose broth at $\mathrm{pH} 7.4$ and the two fold serial dilution technique was applied. A set of tubes containing only inoculated broth was used as controls. For the antibacterial assay after incubation for $37^{\circ} \mathrm{C}$ at $24 \mathrm{~h}$ and after incubation for $48 \mathrm{~h}$ at $25^{\circ} \mathrm{C}$ for the antifungal assay, the last tube with no growth of microorganism and/or yeast was recorded to represent the MIC expressed in ppm. Every experiment in the antibacterial and antifungal assays was replicated twice and the data is given in Table 2. 
Table 2. Antifungal activities of newly synthesized transition metal complexes against $S$. cereviscae and $C$ albicans

\begin{tabular}{|c|c|c|c|c|c|}
\hline \multirow{4}{*}{ Compounds } & \multirow{4}{*}{$\begin{array}{l}\text { I } \\
\stackrel{\Xi}{\Xi}\end{array}$} & \multicolumn{2}{|c|}{ (C. albicans) } & \multicolumn{2}{|c|}{ (S. cereviscae) } \\
\hline & & MTT & 227 & MTT & 361 \\
\hline & & 500 ppm & 1000 ppm & 500 ppm & 1000 ppm \\
\hline & & Inhibitionzone & Inhibition zone & Inhibition zone & Inhibition zone \\
\hline \multirow[t]{2}{*}{ I } & 24 & 4.7 & 7.8 & 6.3 & 7.4 \\
\hline & 48 & 4.7 & 7.9 & 6.5 & 7.6 \\
\hline \multirow[t]{2}{*}{ II } & 24 & 4.2 & 7.7 & 6.4 & 7.6 \\
\hline & 48 & 4.6 & 7.8 & 6.6 & 7.7 \\
\hline \multirow[t]{2}{*}{ III } & 24 & 4.3 & 7.3 & 6.2 & 7.4 \\
\hline & 48 & 4.5 & 7.5 & 6.5 & 7.5 \\
\hline IV & 24 & 4.2 & 7.6 & - & - \\
\hline Amphotericin-B & 48 & 4.5 & 7.8 & - & - \\
\hline In DMSO & 24 & 15.5 & 23.4 & 14.2 & 2.2 \\
\hline (100 ppm) & 48 & 15.5 & 23.4 & 14.2 & 2.2 \\
\hline
\end{tabular}

\section{Results and Discussion}

\section{Infra Red Spectra}

The Infrared spectra of the complexes were obtained in the range 4000-400 $\mathrm{cm}^{-1}$. Several important observations concerning the mode of coordination in these complexes are possible from these data. These are: (1) the carbonyl stretching frequencies provide a very important clue in the elucidation of structures. In a unionized carboxylate group, the $\mathrm{C}=\mathrm{O}$ stretching vibration appears above $1700 \mathrm{~cm}^{-1}$. (2) Infrared spectra of a large number of amine and ammine complexes have been examined by several authors, generally with satisfactory agreement as to exact frequencies in a given compound. The assignment of absorption in the $3000-3300 \mathrm{~cm}^{-1}$ region to N-H stretching frequencies is beyond doubt. It is apparent from the available data that coordination of amines lowers the N-H stretching frequencies by $100-150 \mathrm{~cm}^{-1}$. It has been proposed that the major cause of this lowering is the drainage of electrons from the nitrogen atom which, in turn, weakens the N-H bond. In the absence of these data on some of the free substituted pyridine hydrazine or their salts we compare the spectral band especially above $3000 \mathrm{~cm}^{-1}$ in the metal complexes with their corresponding N-substituted hydrazide, that almost all the absorption bands observed above $3000 \mathrm{~cm}^{-1}$, assigned to N-H or $\mathrm{NH}_{2}$ stretching vibrations, are shifted to lower wave numbers in the complexes as compared to the corresponding free ligand. We interpret the observed shifts to lower energy in the complexes as arising from nitrogen coordination to the metal ions.

Electrochemically, N (1) attached to the carbonyl group in Pyridine 2-Acetyl chloride, should be incapable of bond formation; hence, $\mathrm{N}(2)$ is believed to be involved in coordination to metal ion in its complexes. (3) $N-N$ stretching vibration can be assigned on the basis of preceding work. It has been shown that if the hydrazine radical is attached with a conjugated system then N-N stretching occurs at about $1000 \mathrm{~cm}^{-1}$, either if the resulting group is chelated or not. The distinction between chelated and non-chelated $N$-substituted pyridine hydrazide has been made only by broadening of this band in the chelate. In all our complexes $v(\mathrm{~N}-\mathrm{N})$ vibration appears in the $1030-950 \mathrm{~cm}^{-1}$ region. The slightly broad character of this band in all complexes may be taken as evidence for the nitrogen involvement in the bond formation. Manganese(II), Copper(II), Cobalt(II), and Nickel(II) complexes of N-substituted pyridine hydrazide have been studied in considerable detail and although some derivatives are considered to coordinate solely through nitrogen the majority of they contain $v(M-N)^{27}$ bonds. 


\section{${ }^{1} H$ and ${ }^{13} C$ NMR Spectra}

${ }^{1} \mathrm{H}$ NMR spectrums show a signal in the range $\delta 8.03-8.08 \mathrm{ppm}$, these signals were the evidence of the carbon-nitrogen bonding to the ligand. ${ }^{13} \mathrm{C}$ NMR spectrum of complexes display a signal at $\delta 150.23-151.45 \mathrm{ppm}$ and $\delta 162.76-163.54 \mathrm{ppm}$, due to $(\mathrm{C}-\mathrm{N})$ and $(\mathrm{C}=\mathrm{O})$, which was indicating that carbon atoms of carbon-nitrogen groups and oxygen atoms of carbonyl groups participate to the ligand.

\section{Molar Conductance}

The molar conductance values of all the complexes having bivalelent metal ions lies in the range $122-165 \mathrm{ohm}^{-1} \mathrm{~cm}^{2}$ mole $^{-1}$ corresponding to $1: 2$ electrolytic behavior ${ }^{28}$.

\section{Electronic Spectra and Magnetic Moments}

In the spectrums of UV-Vis spectroscopy, the electronic spectra of $\mathrm{Mn}$ (II) complexes show two bands in the regions $22500-22650$ and $18500-18850 \mathrm{~cm}^{-1}$ which may be assigned to ${ }^{6} \mathrm{~A}_{1 \mathrm{~g}}$ ${ }_{\rightarrow}^{4} \mathrm{~T}_{2 \mathrm{~g}}$ and ${ }^{6} \mathrm{~A}_{1 \mathrm{~g}} \rightarrow{ }^{4} \mathrm{~T}_{1} \mathrm{~g}(\mathrm{G})$ transitions, respectively, suggesting octahedral environment around the $\mathrm{Mn}$ (II) ion ${ }^{29}$. The magnetic moment 4.88 is an additional evidence for an octahedral structure. The electronic spectra of the cobalt(II) complex showed three bands at 8780-8810, 17475-17775 and 30235-30270 $\mathrm{cm}^{-1}$, which may be assigned to ${ }^{4} \mathrm{~T}_{1 \mathrm{~g}} \rightarrow{ }^{4} \mathrm{~T}_{2 \mathrm{~g}}(\mathrm{~F}),{ }^{4} \mathrm{~T}_{1 \mathrm{~g}} \rightarrow$ ${ }^{4} \mathrm{~T}_{1 \mathrm{~g}}(\mathrm{P})$, and ${ }^{4} \mathrm{~T}_{1 \mathrm{~g}} \rightarrow{ }^{3} \mathrm{~A}_{2 \mathrm{~g}}(\mathrm{~F})$ transitions, respectively, and suggested octahedral geometry ${ }^{30-31}$ around the cobalt ion. The electronic spectra of the copper(II) complex display a broad band at $14920 \mathrm{~cm}^{-1}$ due to ${ }^{2} \mathrm{~B}_{1 \mathrm{~g}} \rightarrow{ }^{2} \mathrm{E}_{\mathrm{g}}$ and two bands at 16390 and $27250 \mathrm{~cm}^{-1}$ assigned to $\mathrm{d}-\mathrm{d}$ transitions and a charge transfer band respectively, of an octahedral environment. The magnetic moments in such complex, as in apparent, lie appreciably above the spine-only value $(1.73 \mathrm{BM})$, but as the electronic ground states are non-degenerate this cannot arise from inherent angular momentum in the ground state. It arises due to mixing of some orbital angular momentum from excited states via spin orbit coupling. The copper (II) complex exhibit magnetic moments of 1.78 B.M., respectively, at room temperature. These values are quite close to the spin-allowed values expected for an $\mathrm{S}=1 / 2$ system and may be indicative of a distorted octahedral geometry around copper (II) ion. The nickel(II) complex was insoluble in common organic solvents and water. The compound was soluble in coordinating solvents, pyridine and DMSO, presumably by displacing water molecules from the coordination sphere. The nickel(II) complex exhibited three bands at 9960-10165, 1585016155 and $29940-29985 \mathrm{~cm}^{-1}$ assignable, respectively to the transitions ${ }^{3} \mathrm{~A}_{2 \mathrm{~g}}(\mathrm{~F}) \rightarrow{ }^{3} \mathrm{~T}_{2 \mathrm{~g}}(\mathrm{~F})$ $(v 1),{ }^{3} \mathrm{~A}_{2 \mathrm{~g}}(\mathrm{~F}) \rightarrow{ }^{3} \mathrm{~T}_{1 \mathrm{~g}}(\mathrm{~F})\left(v_{2}\right)$, and ${ }^{3} \mathrm{~A}_{2 \mathrm{~g}}(\mathrm{~F}) \rightarrow{ }^{3} \mathrm{~T}_{2 \mathrm{~g}}(\mathrm{P})\left(v_{3}\right)$, which are characteristic of nickel(II) in octahedral geometry. Magnetic behavior of octahedral nickel(II) complex is relatively simple. From both the simple ' $d$ ' orbital splitting diagram and the energy level diagram, all the octahedral complexes of the divalent nickel should have two unpaired electrons. The experimental magnetic moment values usually lie in range 2.9 to $3.4 \mathrm{BM}$, a little higher than spin only value (2.83). The magnetic moment value of $N$-substituted hydrazine complex is $3.14 \mathrm{BM}$, indicating the octahedral arrangement of ligand around nickel(II) ion in the complex. The electronic spectra of the cobalt(II) complex showed three bands at 8780-8810, 17475-17775 and 30235-30270 $\mathrm{cm}^{-1}$, which may be assigned to ${ }^{4} \mathrm{~T}_{1 \mathrm{~g}} \rightarrow$ ${ }^{4} \mathrm{~T}_{2 \mathrm{~g}}(\mathrm{~F}),{ }^{4} \mathrm{~T}_{1 \mathrm{~g}} \rightarrow{ }^{4} \mathrm{~T}_{1 \mathrm{~g}}(\mathrm{P})$, and ${ }^{4} \mathrm{~T}_{1 \mathrm{~g}} \rightarrow{ }^{3} \mathrm{~A}_{2 \mathrm{~g}}(\mathrm{~F})$ transitions, respectively, and suggested octahedral geometry around the cobalt ion. The cobalt(II) complex shows magnetic moment values $^{32}$ of 4.85 B.M. at room temperature. This high value of the magnetic moments and the stoichiometries suggest a coordination number of six for the central cobalt(II) ion and an octahedral geometry. On the basis of the above observations, it is tentatively suggested that all of the complexes show an octahedral geometry (Scheme 2) in which the two ligands act as bidentates. These possibly accommodate themselves around the 
metal atom in such a way that a stable chelate ring is formed giving, in turn, stability to the formed metal complexes.

\section{Conclusion}

In this article we have described that the all the synthesized transition metal complexes of Bis(Pyridine-2-carbo) hydrazide has octahedral geometry. The results of antimicrobial activities show that the metal-complexes exhibit antimicrobial properties and it is important to note that they show enhanced inhibitory activity compared to parent ligand. All the investigated compounds showed less to good activity against $S$. aureus.

\section{Acknowledgment}

The authors are thankful to SAIF, CDRI, Lucknow, SARC, Meerut and ACBR, New Delhi, India, for providing the spectral, analytical facilities, and biological activity, respectively.

\section{References}

1. Bolognes G, Correale M, Manfra A, Lavecchia E, Novellino and Pepe S, J Med Chem., 2006, 49, 5110-5118.

2. Xin Z, Serby M D, Zhao H, Kosogof, CSzczepankiewicz B G, Liu M, Liu B, Hutchins CW, Sarris K A, Hoff E D, Falls, H D, Lin CW, Ogiela C A, Collins C A, Brune M E, Bush E N, Droz B A, Fey T A, Knourek-Segel V E, Shapiro R, Jacobson P B, Beno D W, Turner T M, Sham H L and Liu G, J Med Chem., 2006, 49, 4459-4469.

3. Silva G A, Costa L M M , Brito F C F, Miranda A L P, Barreiro E J and Fraga C A M, Bioorg Med Chem., 2004, 12, 3149-3158.

4. Salgın-Gokşen U, Gokhan-Kelekçi N, Goktaş O, Koysal Y, Kılıç E, Işık S and Aktay G O, Bioorg Med Chem., 2007, 15, 5738-5751.

5. Duarte C D, Tributino J L M, Lacerda D I, Martins M V, Alexandre-Moreira M S, Dutra F, Bechara E J H, De-Paula F S, Goulart M O F, Ferreira J, Calixto J B, Nunes M P, Bertho A L, Miranda A L P, Barreiro E J and Fraga C A M, Bioorg Med Chem., 2007, 15, 2421-2433.

6. Walcourt A, Loyevsky M, Lovejoy D B, Gordeuk V R and Richardson D R, Int J Biochem Cell Biol., 2004, 36, 401-407.

7. Gemma S, Kukreja G, Fattorusso C, Persico M, Romano M, Altarelli M, Savini L, Campiani G, Fattorusso E and Basilico N, Bioorg Med Chem Lett., 2006, 16, 53845388 .

8. Wing L K, Behanna H A, Van Eldik L J, Watterson D M and Ranaivo H R, Curr Alzheimer Res., 2006, 3, 205-214.

9. Bernardino A, Gomes A, Charret K, Freitas A, Machado G, Canto-Cavalheiro M, Leon L and Amaral V, Eur J Med Chem., 2006, 41, 80-87.

10. Halli M B and Patil U B, Indian J Chem., 2011, 50 A, 664-667.

11. Kuçukguzel S G, Rollas S, Erdeniz H and Kiraz M, Eur J Med Chem., 1999, 34, 153-160.

12. Tavares LC, Chiste J J, Santos M G B and Penna T C V, Boll Chim Farm., 1999, 138, 432-436.

13. Ulusoy N, Çapan G, Otuk G and Kiraz M, Boll Chim Farm., 2000, 139, 167-172.

14. Turan-Zitouni G, Blache Y and Güven K, Boll Chim Farm., 2001, 140, 397-400.

15. Vicini P, Zani F, Cozzini P and Doytchinova I, Eur J Med Chem., 2002, 37, 553-564.

16. Kucukguzel S G, Mazi A, Şahin F, Ozturk S and Stables J P, Eur J Med Chem., 2003, 38, 1005-1009. 
17. Loncle C, Brunel J, Vidal N, Dherbomez M, and Letourneux Y, Eur J Med Chem., 2004, 39, 1067-1071.

18. Heimer G, Etizion M R, Gad I B, Goldberg J A, Haber S N, and Bergman H, J Neurol Sci., 2006, 6, 8101-8114.

19. Masunari A and Tavares L C, Bioorg Med Chem., 2007, 15, 4229-4236.

20. Cocco M T, Congiu C, Onnis V, Pusceddo M C, Schivo M L, and De Logu A, Eur J Med Chem., 1999, 34, 1071-1076.

21. Bukowski L, Janowiec M, Zwolska-Kwiek Z, and Andrzejczyk Z, Pharmazie., 1999, 54, 651-654.

22. Savini L, Chiasserini L, Gaeta A, and Pellerano C, Bioorg Med Chem., 2002, 10, 2193-2198.

23. Rando D, Sato D N, Siqueira L, Malvezzi A, Leite C Q F, Amaral A T, Ferreira E I and Tavares L C, Bioorg Med Chem., 2002, 10, 557-560.

24. Mamolo M G, Falagiani V, Zampieri D, Vio L, Banfi E, and Scialino G, Farmaco., 2003, 58, 631-637.

25. Sriram D, Yogeeswari P, and Madhu K, Bioorg Med Chem Lett., 2005, 15, 4502-4505.

26. Shindikar AV and Viswanathan C L, Bioorg Med Chem Lett., 2005, 15, 1803-1806.

27. Sinha N, Jain S, Tilekar A, Upadhayaya RS, Kishore N, Jana G H, and Arora S K, Bioorg Med Chem Lett., 2005, 15, 1573-1576.

28. Geary W J, Wilson R J W, Silverman K N, Gayhard O V and Hilton T V, Coord Chem Rev., 1971, 7, 81-122.

29. Lever A B P, Inorganic Electronic Spectroscopy, Elsevier, Amsterdam., 1984.

30. El-Ashry E H and Ibrahim E I, Adv Heter Chem., 2003, 84, 71-190.

31. Almeida P E, Ramos D F, Bonacorso H G, Iglesia A I, Oliveira M R, Coelho T, Navarini J, Morbidoni H R, Zanatta N, and Martins M A, J Antimicr Agents., 2008, 32, 139-144.

32. Kumar P, Narasimhan B, Sharma D, Vikramjeet Judge V, and Narang R, Eur J Med Chem., 2009, 44, 1853-1863. 


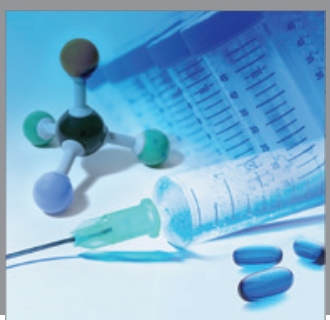

International Journal of

Medicinal Chemistry

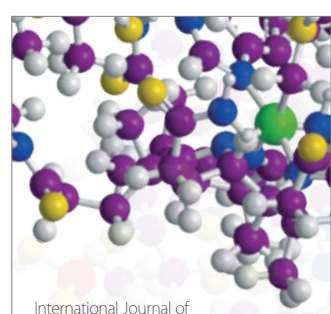

Carbohydrate Chemistry

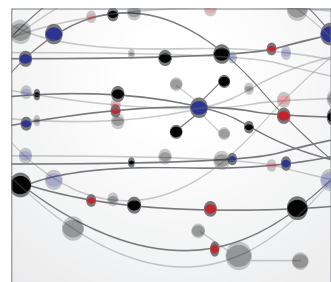

The Scientific World Journal
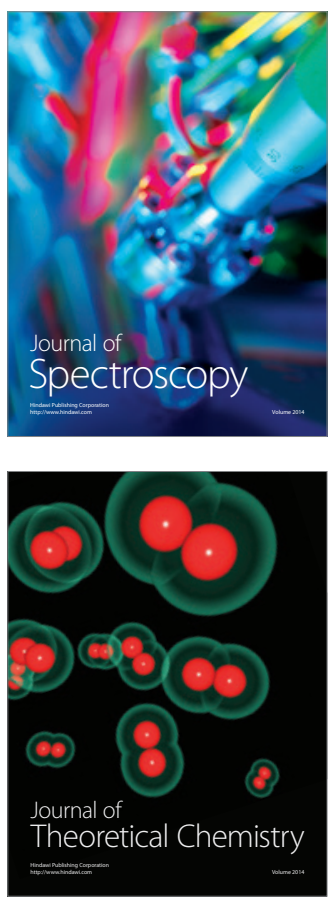
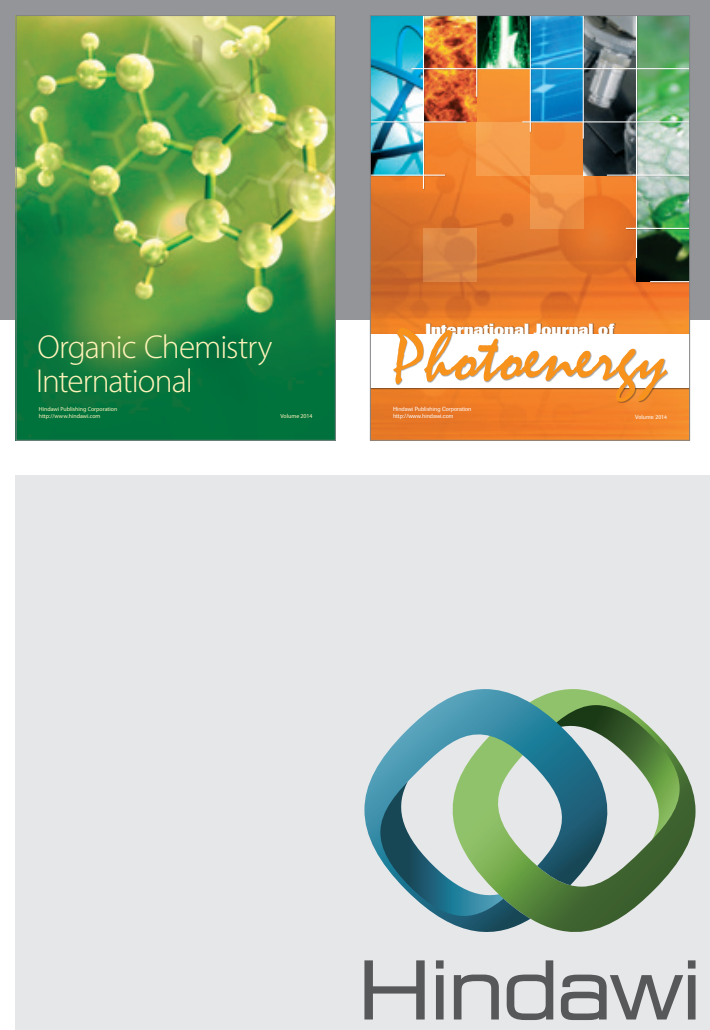

Submit your manuscripts at

http://www.hindawi.com
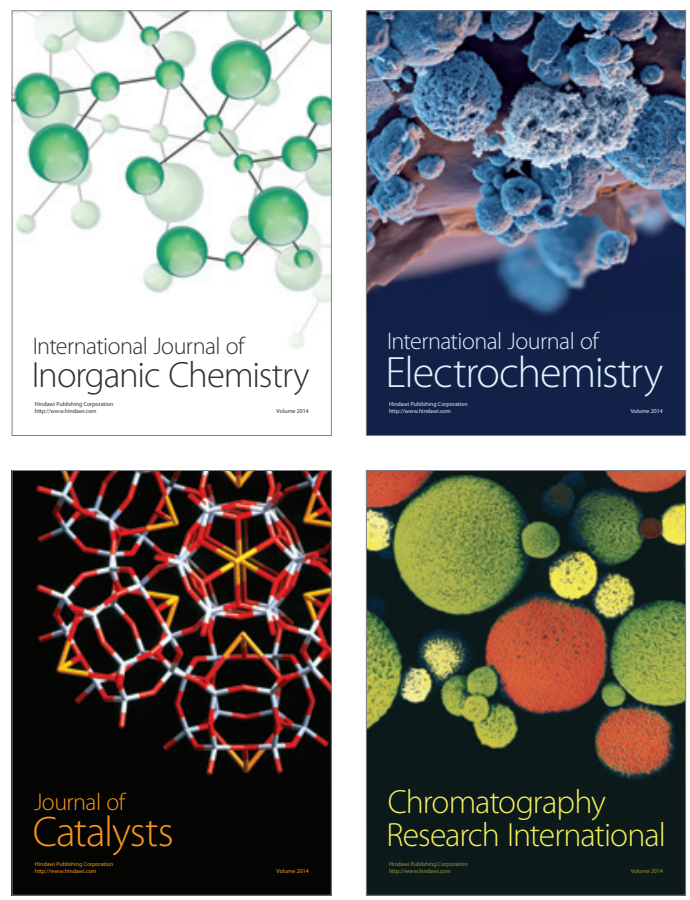
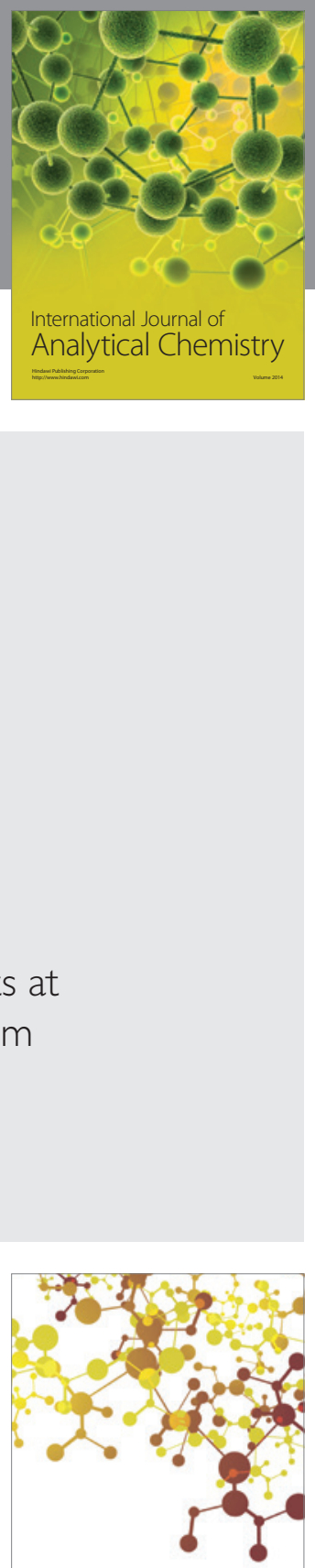

Journal of

Applied Chemistry
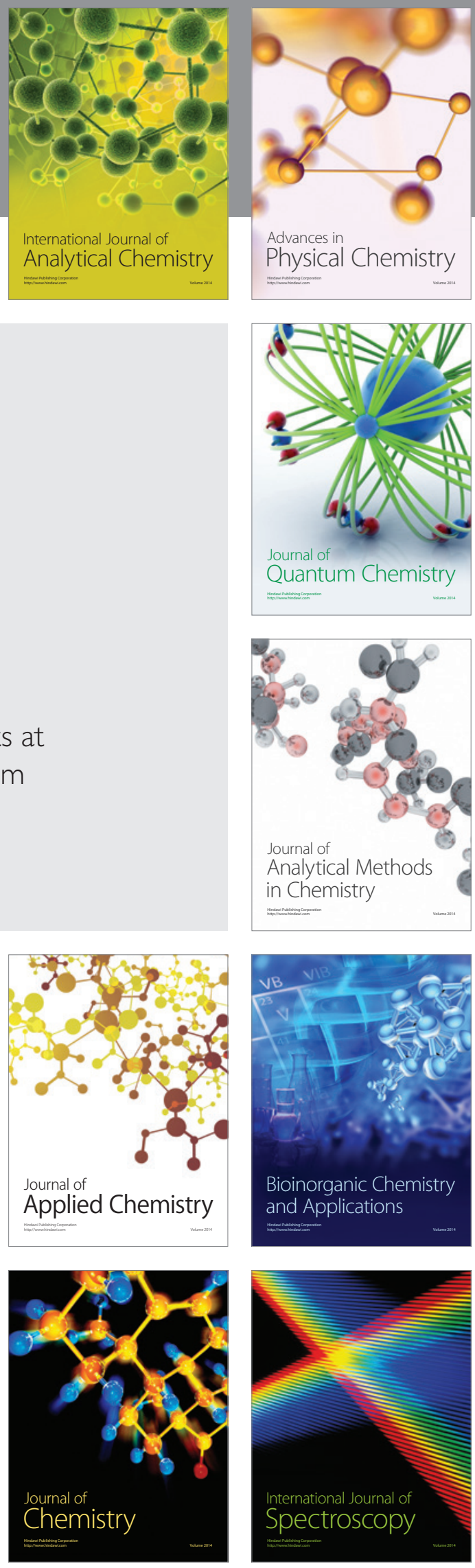